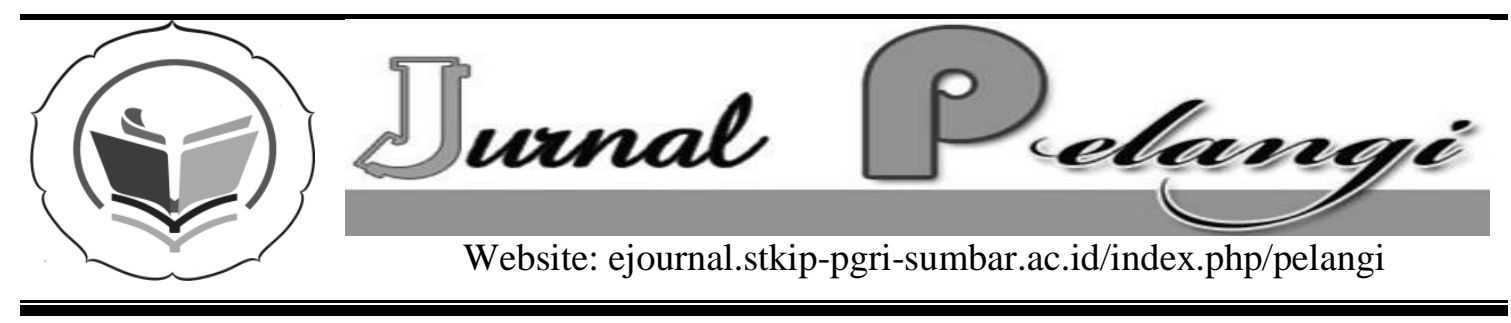

\title{
PENGEMBANGAN KIT ELEKTROKIMIA KELAS XII SMA
}

\section{Ratulani Juwita}

STKIP PGRI Sumatera Barat, ratulanijuwita@gmail.com

\section{INFO ARTIKEL}

\section{Diterima:}

1 Desember 2015

Direview:

8 Desember 2015

Disetujui:

22 Desember 2015

\section{Kata Kunci:}

KIT, Validitas, Praktikalitas, efektivitas

\begin{abstract}
Abstrak
Media pembelajaran merupakan faktor yang sangat penting dalam proses pembelajaran. Dalam rangka penyediaan media pembelajaran untuk pembelajaran kimia SMA dikembangkan Kit Elektrokimia untuk pelaksanaan percobaan di dalam kelas. Oleh karena itu, penelitian ini bertujuan untuk mengembangkan media pembelajaran kimia berupa Kit Elektrokimia SMA yang valid, praktis dan efektif. Jenis penelitian adalah penelitian pengembangan dengan menggunakan pola pengembangan Gustafson \& Branch. Model pengembangan ini menerapkan prinsip-prinsip pendekatan sistem yang terdiri dari lima tahapan, yaitu analisis, perancangan, pengembangan, evaluasi, dan implementasi . Pada penelitian ini, media pembelajaran yang dibuat hanya dikembangkan sampai tahap pengembangan. Tahap analisis, yaitu menganalisis kurikulum dan analisis siswa. Pada tahap perancangan dilakukan perancangan media pembelajaran. Sedangkan pada tahap pengembangan, rancangan perangkat pembelajaran yang telah dirancang kemudian divalidasi oleh 2 orang validator dibidang ilmu kimia dan 1 orang validator dibidang evaluasi pendidikan. Media pembelajaran yang telah direvisi berdasarkan saran dan koreksi validator kemudian diujicobakan secara terbatas pada 31 orang siswa kelas XI IPA1 SMAN 1 Gunung Talang Kabupaten Solok Sumatera Barat. Uji coba bertujuan untuk melihat praktikalitas perangkat pembelajaran yang telah dikembangkan, sedangkan efektivitas yang diamati adalah hasil belajar siswa. Analisis data yang digunakan adalah statistik deskriptif kualitatif untuk memvalidasi media pembelajaran oleh validator, serta praktikalitas media pembelajaran oleh guru dan siswa. Berdasarkan penilaian dari validator, Kit Elektrokimia dikategorikan valid. Sementara nilai praktikalitas berdasarkan pengamatan respon guru dan siswa dikategorikan praktis. Efektivitas dari hasil belajar ranah kognitif siswa dalam kategori baik dengan
\end{abstract}


ketuntasan klasikal di atas $90 \%$. Kesimpulan dari penelitian ini adalah Kit Elektrokimia kelas XII SMA yang dikembangkan sudah valid, praktis, dan efektif pada standar kompetensi menerapkan konsep reaksi oksidasi-reduksi dan elektrokimia dalam teknologi dan kehidupan sehari-hari.

\begin{abstract}
Learning media is a very important factor in the learning process. In the framework of the provision of instructional media for teaching high school chemistry Electrochemistry Kit developed for the implementation of experiments in the classroom. Therefore, this study aimed to develop chemistry learning media in the form of Electrochemistry Kit SMA valid, practical and effective. This type of research is the development of research using patterns of development Gustafson \& Branch. This development model to apply the principles of systems approach that consists of five stages: analysis, design, development, evaluation, and implementation. In this study, learning media created just developed to the stage of development. Phase analysis, which analyzes the curriculum and student analysis. At the design stage to design instructional media. Whereas at this stage of development, the design of learning tools that have been designed and then validated by 2 validator field of chemistry and the first person in the field of educational evaluation validator. Media that has been revised based on suggestions and corrections validator then tested on a limited basis to the 31 students of class XI IPAl SMAN 1 Gunung Talang in Solok regency of West Sumatera. The trial aims to look at the practicalities of learning tools that have been developed, whereas the observed effectiveness is student learning outcomes. Analysis of the data used is qualitative descriptive statistics to validate learning media by the validator, as well as the practicalities of learning media by teachers and students. Based on an assessment of the validator, Electrochemistry Kit categorized as invalid. While the practicalities value is based on observations of teacher and student responses categorized as practical. The effectiveness of cognitive learning outcomes of students in both categories with classical completeness above $90 \%$. The conclusion from this study is the high school class XII Electrochemistry Kit developed is valid, practical, and effective on competency standards applying the concept of oxidation-reduction reactions and electrochemistry in technology and everyday life.
\end{abstract}

\section{PENDAHULUAN}

Percobaan atau praktikum di laboratorium yang dilaksanankan dalam pembelajaran Kimia bertujuan untuk lebih meningkatkan pemahaman siswa terhadap suatu konsep materi kimia. Berdasarkan kegiatan praktikum ini dapat dilakukan penilaian hasil kerja dan penilaian sikap. Sehingga dalam kegiatan pembelajaran dibutuhkan beberapa media yang dapat membantu kelancaran proses pembelajaran itu sendiri termasuk media yang digunakan dalam pelaksanaan praktikum. 
Media pembelajaran yang diguna-kan merupakan salah satu faktor penentu keberhasilan pembelajaran. Media pembelajaran memiliki peranan yang penting antara lain sebagai pedoman bagi guru untuk mengarahkan semua aktivitasnya dalam pembelajaran dan sebagai sumber belajar utama bagi siswa. Badan Standar Nasional Pendidikan (BSNP) yang merupakan badan standarisasi, penjamin, dan pengendali mutu pendidikan Indonesia mengeluarkan suatu pedoman untuk menelaah buku teks pelajaran dan media pembelajaran yang meliputi kelayakan isi (kesesuaian materi dengan standar kompetensi dan kompetensi dasar, keakuratan materi, materi pendukung pelajaran) dan kelayakan penyajian (teknik penyajian, penyajian pembelajaran, kelengkapan penyajian). Oleh karena itu, media pembelajaran harus memenuhi persyaratan tersebut agar layak pakai.

Salah satu pokok bahasan kimia yang diajarkan di SMA kelas XII IPA adalah pokok bahasan elektrokimia. Pokok bahasan elektrokimia memiliki keluasan dan kedalaman materi yang dikembangkan berdasarkan standar isi. Banyaknya konsep yang harus dipelajari dalam pokok bahasan elektrokimia dibutuhkan banyak waktu untuk mempelajarinya termasuk praktikum yang harus dilakukan untuk lebih mengetahui aplikasi eletrokimia dalam kehidupan sehari-hari. Oleh karena itu, diperlukan solusi agar materi pelajaran tersebut dapat dijelaskan secara lengkap dan waktu yang terbatas dapat kita gunakan secara efektif.

Tujuan akhir yang ingin dicapai dalam setiap pembelajaran adalah empat pilar pendidikan yang telah dicanangkan United Nations Educational Scientific Culture Organization (UNESCO), yaitu learning to know, learning to do, learning to live together, dan learning to be dapat berfungsi optimal. Dalam rangka mencapai tujuan tersebut, diperlukan suatu analisis kebutuhan untuk mengetahui kelengkapan pembelajaran apa saja yang harus dipenuhi oleh pendidik agar pembelajaran berlangsung secara optimal dan tujuan pembelajaran dapat tercapai. Kelengkapan pembelajaran yang harus dipenuhi diantaranya: RPP, bahan ajar, alat evaluasi, dan media pembelajaran.

Hasil survei terhadap beberapa sekolah di Sumatera Barat menunjukkan bahwa kurangnya penggunaan media pembelajaran pada pokok bahasan elektrokimia, dan hasil survei terhadap beberapa perusahaan penyedia alat-alat perlengkapan praktikum untuk sekolah, Kit untuk materi elektrokimia belum tersedia, sedangkan beberapa sekolah belum mempunyai laboraorium dengan alat dan bahan yang diperlukan untuk pelaksanaan praktikum. Berdasarkan temuan tersebut, maka diperlukan perbaikan terhadap perangkat pembelajaran pokok bahasan elektrokimia yang disertai dengan beberapa media yang sesuai untuk pokok bahasan tersebut, yaitu berupa Kit.

Kit merupakan alat praktikum yang sederhana sehingga siswa dapat melakukan percobaan secara berkelompok di dalam kelas. Kit ini dapat digunakan untuk mengembangkan ranah berpikir kognitif, afektif dan psikomotor. Diharapkan dengan menggunakan kit siswa dapat berpikir secara ilmiah dan mampu menganalisis temuantemuannya selama melakukan percobaan secara ilmiah. Kit yang digunakan dalam pembelajaran diharapkan dapat membantu dalam proses pencapaian tujuan pembelajaran. Kit sebagai media pembelajaran merupakan salah satu sumber belajar yang digunakan sebagai penghubung pesan ajar yang didesain secara terencana oleh guru untuk menciptakan lingkungan belajar yang kondusif bagi siswa-siswanya. Sesuai dengan defenisi media yang dikemukakan oleh Munadi (2008: 7) media pembelajaran dapat dipahami sebagai segala sesuatu yang dapat menyampaikan dan menyalurkan pesan dari sumber secara terencana sehingga tercipta lingkungan belajar yang kondusif dimana penerimanya dapat melakukan proses belajar secara efisien dan efektif. Melihat begitu besarnya pengaruh Kit dalam pembelajaran elektrokimia yaitu untuk memudahkan pelaksanaan praktikum dan memberikan pemahaman yang kuat terhadap materi elektrokimia maka perlu diteliti validitas, praktikalitas, dan efektivitas untuk 
digunakan dalam proses pembelajaran. Media pembelajaran yang dibuat berupa Kit yang telah didesain dan dibuat untuk mengajarkan elektrokimia kelas XII IPA.

\section{Mengajar dan Pembelajaran}

Menurut Sanjaya (2008: 215) dalam konteks implementasi kurikulum mengajar bukan hanya sekadar penyampaian materi pelajaran, akan tetapi juga dimaknai sebagai proses mengatur lingkungan supaya siswa belajar. Makna lain mengajar yang demikian sering diistilahkan dengan pembelajaran. Hal ini mengisyaratkan bahwa dalam proses belajar mengajar siswa harus dijadikan sebagai pusat dari kegiatan. Ini dimaksudkan untuk membentuk watak, peradaban, dan meningkatkan mutu kehidupan peserta didik.

Pembelajaran perlu memberdayakan semua potensi peserta didik untuk menguasai kompetensi yang diharapkan. Pemberdayaan diarahkan untuk mendorong pencapaian kompetensi dan perilaku khusus supaya setiap individu mampu menjadi pembelajar sepanjang hayat dan mewujudkan masyarakat belajar.

Secara konseptual pada dasarnya istilah mengajar itu juga bermakna membelajarkan siswa. Menurut Aunurrahman (2009: 4-5) mengajar adalah suatu aktivitas yang dapat membuat siswa belajar, sehingga dalam konteks pembelajaran sama sekali tidak berarti memperbesar peranan siswa di satu pihak dan memperkecil peranan guru di pihak lain. Guru tetap harus berperan secara optimal demikian juga halnya dengan siswa. Perbedaan dominasi dan aktivitas ditunjukkan dari perbedaan tugas-tugas atau perlakuan guru dan siswa terhadap materi dan proses pembelajaran.

Guru saat ini berperan sebagai fasilitator proses pembelajaran di kelas yang menyiapkan fasilitas pembelajaran, yang meliputi berbagai sumber belajar, alat belajar, dan bantuan belajar. Siswa ditempatkan pada proses pembelajaran berpikir, pengetahuan yang diperoleh siswa tidak datang dari luar, akan tetapi dibentuk oleh siswa itu sendiri dalam struktur kognitif yang dimilikinya. Berdasarkan hal tersebut pembelajaran berpikir memandang bahwa mengajar bukanlah memindahkan pengetahuan dari guru kepada siswa, melainkan suatu aktivitas yang memungkinkan siswa dapat membangun sendiri pengetahuan-nya.

\section{Perangkat Pembelajaran}

Perangkat yang dipergunakan dalam proses pembelajaran disebut perangkat pembelajaran. Berdasarkan Peraturan Pemerintah Republik Indonesia Nomor 19 tahun 2005 tentang standar nasional pendidikan, pasal 20 yang berbunyi "Perencanaan proses pembelajaran meliputi silabus dan rencana pelaksanaan pembelajaran yang memuat tujuan pembelajaran, materi ajar, metode pengajaran, sumber belajar, dan penilaian hasil belajar". PP nomor 19 tahun 2005 pasal 20 ini secara umum menjelaskan bahwa RPP termasuk dalam perangkat pembelajaran yang harus dipersiapkan setiap guru pada setiap satuan pendidikan sebelum melaksana-kan suatu proses belajar mengajar.

\section{Media dalam Proses Pembelajaran}

Media pembelajaran merupakan segala sesuatu yang dapat menyampaikan dan menyalurkan pesan dari sumber secara terencana sehingga tercipta lingkungan belajar yang kondusif, dimana penerimanya dapat melakukan proses belajar secara efisien dan efektif.

Proses belajar mengajar pada hakekatnya adalah proses komunikasi, penyampaian pesan dari pengantar kepada penerima. Pesan berupa isi/ajaran yang dituangkan ke dalam simbol-simbol komunikasi baik verbal (kata-kata dan tulisan) maupun non-verbal, proses ini dinamakan encoding. Penafsiran simbolsimbol komunikasi tersebut oleh siswa dinamakan decoding. Dalam penafsiran tersebut ada kalanya berhasil, dan ada kalanya tidak berhasil atau gagal. Dengan kata lain dapat dikatakan ketidakberhasilan dalam memahami apa yang didengar, dibaca, dilihat atau diamati. Ketidakberhasilan tersebut disebabkan oleh gangguan yang menjadi penghambat komunikasi yang dinamakan barriers atau noise. Oleh karena hal tersebut dibutuhkan media dalam pembelajaran, dimana media merupakan saluran komunikasi tempat 
berlalunya pesan dan tanggapan, sehingga penyampaian materi lebih efisien dan efektif (Munadi,2008: 5-14).

Gambaran yang paling banyak dijadikan acuan sebagai landasan teoritis pemanfaatan media dalam proses pembelajaran adalah Dale's Cone of Experience (Kerucut Pengalaman Dale). Dalam usaha pemanfaatan media dalam proses pembelajaran, Edgar Dale melakukan klasifikasi pengalaman dari tingkat yang paling konrit ke tingkat yang paling abstrak. Tingkat pengalaman dalam kerucut tersebut berdasarkan seberapa banyak indera yang terlibat di dalamnya seperti yang disajikan pada Gambar 1.

Kerucut pengalaman Edgar Dale menunjukkan tingkat pengalaman yang diterima oleh peserta didik, di mana media berbentuk teks mempunyai Degree of Abstraction yang tinggi karena peserta didik harus memahami dan mengerti tentang materi yang diberikan dalam bentuk teks tersebut. Degree of Abstraction semakin menurun dengan peningkatan pengalaman yang diterima peserta didik, misalnya jika media instruksional hanya berbentuk teks tidak mampu memberikan pengalaman yang lebih dari panca indera selain mata, tetapi dengan media yang lebih kompleks misalnya simulasi-role play akan memberikan pengalaman yang lebih banyak karena lebih banyak anggota tubuh terlibat, temasuk panca indera. Semakin banyak anggota tubuh yang terlibat dalam proses pembelajaran, maka tingkat kompetensi yang diperoleh peserta didik juga semakin banyak. Jadi secara tidak langsung kerucut pengalaman tersebut menjelaskan bahwa pengalaman belajar langsung sampai ke pengalaman belajar melalui simbol-simbol, yang merentang dari hal yang bersifat konkrit ke abstrak memberikan implikasi tertentu terhadap pengembang-an teknologi pembelajaran. Berdasarkan hal tersebut maka dikembangkan Kit Elektrokimia, karena dengan Kit siswa melaksanakan praktikum yang melatih kemampuan analisa, ketelitian, pengamatan dan pengkomunikasian apa yang dilihat selama proses percabaan berlangsung, sehingga semua indera terlibat dalam proses pembelajaran yang diharapkan pembelajaran semakin bermakna, efektif dan efisien.

\section{Kit sebagai Media Pembelajaran}

Noerdin (1995) menyatakan bahwa Kit adalah seperangkat alat dan bahan yang membantu proses belajar mengajar serta praktikum berjalan lancar, praktis dan ekonomis. Dengan adanya Kit, maka praktikum dapat juga dilaksanakan di dalam kelas/tanpa laboratorium. Pada dasarnya kemampuan belajar (hasil belajar) dipengaruhi oleh interaksi dan kondisi proses pembelajaran. Kondisi pembelajaran yang dikelola dengan baik dalam penggunaan kit akan menciptakan suasana belajar yang menyenangkan sehingga dapat mendorong siswa aktif terlibat dalam proses pembelajaran dan meningkatkan hasil belajarnya.

Arifin (2005:110) mengemukakan bahwa paktikum yang dilakukan didalam kelas mempunyai pesyaratan sebagai berikut:

1. Percobaan tidak menghasilkan gas beracun

2. Alat atau zat sudah tersedia dalam kotak untuk setiap individu atau kelompok dalam mempermudah pelaksanaan.

Kit praktikum memberikan beberapa kelebihan seperti yang dikemukakan oleh Sumiaty (2002:38) yaitu:

1. Kit praktikum dapat membantu sekolah yang tidak mempunyai laboratorium

2. Kit praktikum dapat menggantikan kegiatan praktikum di laboratorium

3. Kit praktikum dapat meningkatkan pemahaman konsep siswa terhadap pelajaran kimia

4. Kit praktikum mudah dibawa

Alat dan bahan untuk praktikum sudah tersedia di dalam kotak sehingga dapat mengatasi kendala guru dalam penyiapan alat dan bahan.

\section{METODE PENELITIAN}

Jenis penelitian ini termasuk dalam kategori penelitian dan pengembangan (Research \& Development), yang mencoba menghasilkan suatu produk baru dalam pembelajaran yaitu sebuah kit praktikum 
untuk mengajarkan elektrokimia kelas XII IPA.

Penelitian pengembangan bertujuan untuk menghasilkan perangkat pembelajaran, seperti silabus, bahan ajar, media, modul praktikum, lembar kegiatan siswa, alat mengukur kemajuan belajar, alat mengukur hasil belajar, dan sebagainya (Latief, 2009: 2). Perlunya dilakukan penelitian pengembangan karena adanya masalah yang terkait dengan perangkat pembelajaran yang kurang tepat.

Produk yang dihasilkan diujicoba pada siswa kelas XI IPA semester 2 SMA Negeri 1 Gunung Talang. Uji coba dilakukan pada siswa kelas XI IPA karena siswa di kelas ini telah memenuhi prasyarat untuk mempelajari materi ini. Materi prasyarat yang harus dikuasai oleh siswa adalah tata nama dan persamaan reaksi kimia, stoikiometri, larutan elektrolit dan daya hantar listrik, dan reaksi redoks. Materimateri tersebut telah dipelajari oleh siswa pada kelas X SMA.

Penelitian ini menggunakan model core elements of instructional development yang dikembangkan oleh Gustafson dan Branch (1997). Model pengembangan ini menerapkan prinsip-prinsip pendekatan yang terdiri dari lima tahapan, yaitu analisa (analyze), perancangan (design), pengembangan (develop), evaluasi (evaluate), dan implementasi (implement). Penelitian ini hanya dilakukan sampai tahap pengembangan (develop) saja. Model pengembangan Gustafson dan Branch dapat dilihat pada Gambar 2.

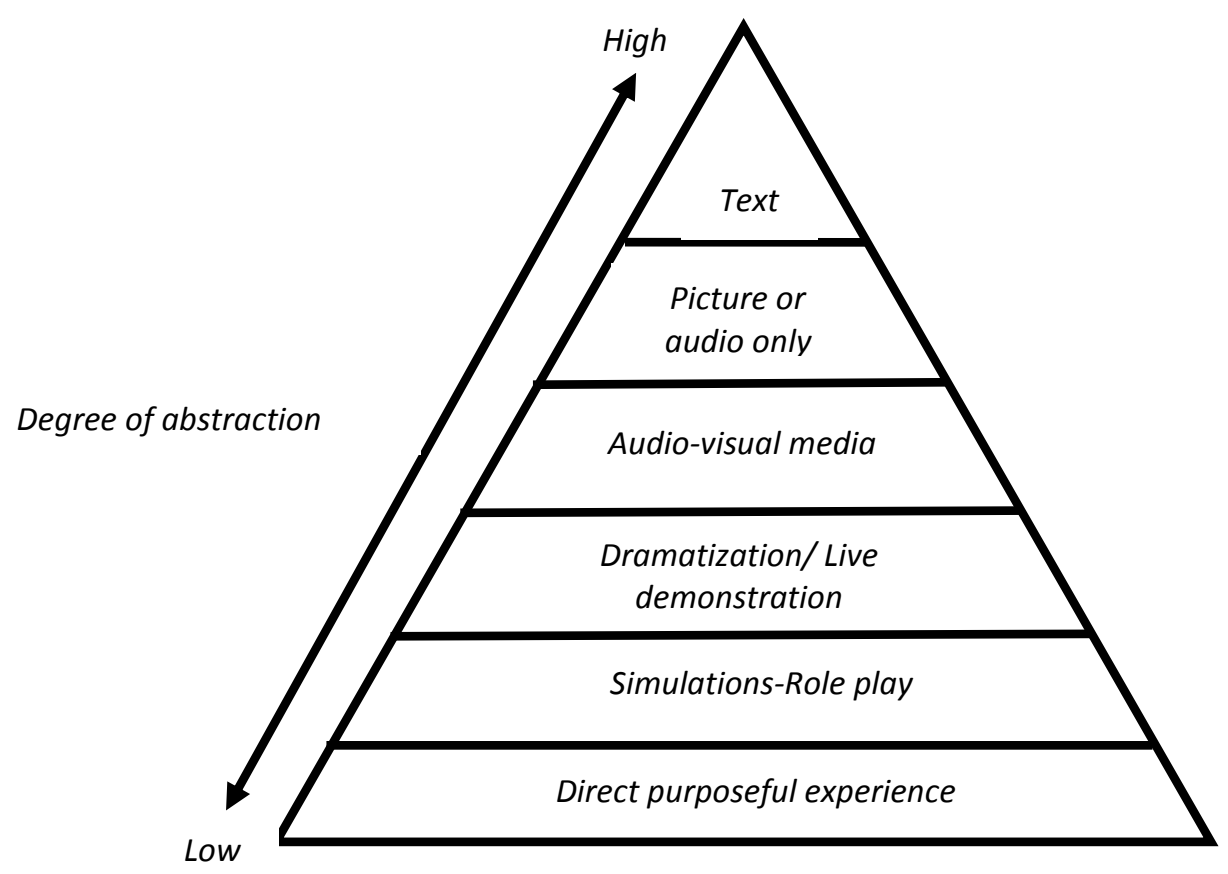

Gambar 1. Kerucut Pengalaman Edgar Dale (Chomsin, 2008: 31)

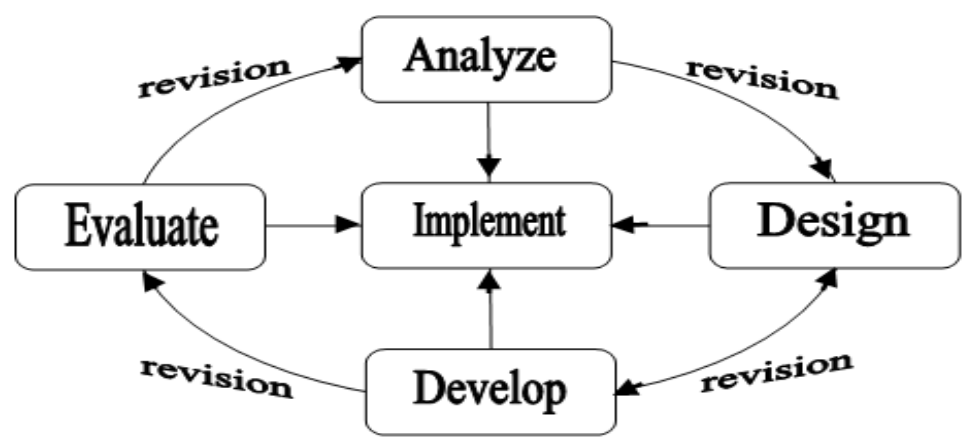

Gambar 2. Pola Pengembangan Gustafson \& Branch (McKenney, 2001: 94) 
Gambar 2 menjelaskan bahwa suatu penelitian pengembangan bertitik tolak pada implementasi di lapangan yang terjadi selama ini. Berdasarkan implementasi tersebut dilakukanlah suatu analisis kebutuhan. Berdasarkan analisis kebutuhan tersebut dilakukan suatu revisi untuk mencari masalah yang sifatnya essensial (pokok). Berdasarkan masalah essensial yang diperoleh dilakukan langkah perancangan produk. Produk yang dirancang harus tetap mengacu pada implementasi selama ini, dengan tujuan menghasilkan produk yang memiliki nilai lebih/ciri khas dibandingkan produk sebelumnya. Hasil rancangan kemudian direvisi agar diperoleh produk dengan kualitas yang baik dan mempunyai nilai lebih jika dibandingkan dengan produk yang dipakai selama ini. Hasil desain yang sudah direvisi dikembangkan dengan tujuan agar lebih bagus dan tidak menyimpang dari konteks yang telah diimplementasikan sebelumnya. Hasil pengembangan direvisi dengan tujuan untuk mendapatkan produk yang sesuai dengan harapan dan dilanjutkan dengan tahap uji coba, yaitu pemakaian produk di lapangan. Hasil uji coba digunakan untuk mengevaluasi produk yang telah dikembangkan dan hasil evaluasi dapat dijadikan acuan untuk pemakaian produk pada kondisi yang berbeda.

\section{Tahap Analisis (Analyze)}

Jenis analisis yang dilakukan adalah analisis konsep esensial. Analisis konsep esensial adalah langkah untuk menjabarkan materi pokok menjadi konsep-konsep penyusunnya. Setelah itu dilakukan pemilihan konsep esensial, yaitu proses pemilihan beberapa konsep utama untuk dikembangkan menjadi bahan ajar atau media pembelajaran dengan memperhatikan SK, KD dan indikator yang akan dicapai. Sesuai dengan penelitian ini, maka analisis konsep dilakukan pada pokok bahasan "elektrokimia". Setelah konsep-konsep esensial dipilih, baru dilakukan perancangan media pembelajaran.

\section{Tahap Desain (Design)}

Menurut kamus besar Bahasa Indonesia (1994: 227), desain adalah rancangan, rencana suatu bentuk, dan sebagainya. Pada tahapan ini terlebih dahulu ditentukan jenis media pembelajaran yang akan dikembangkan, berdasarkan KD dan indikator yang telah dirumuskan pada tahap analisis, maka dipilih Kit sebagai pengembangan media pembelajaran. Setelah ditetapkan jenis media pembelajaran yang akan dirancang, maka disiapkan skenario pembelajaran dengan menggunakan kit yaitu dalam bentuk praktikum.

\section{Tahap Pengembangan (Develop)}

Pada tahapan pengembangan ini dilakukan validasi produk. Validasi produk merupakan proses kegiatan untuk menilai apakah rancangan produk, berdasarkan pemikiran rasional para ahli (validator) sudah layak untuk digunakan. Validasi produk dilakukan dengan cara menghadirkan para ahli atau pakar yang sudah berpengalaman untuk menilai produk baru yang telah dirancang. Validasi produk ini bertujuan untuk mengetahui kelemahan dan kekuatan produk yang telah dibuat. Setelah produk divalidasi melalui diskusi dengan pakar atau ahli, maka akan diketahui kelemahan produk. Selanjutnya kelemahan tersebut dicoba untuk dikurangi dengan cara memperbaiki desain produk (revisi). Produk yang telah divalidasi dan direvisi dicobakan untuk digunakan dalam proses belajar mengajar. Berdasarkan data yang diperoleh dari hasil uji coba dapat diketahui praktikalitas dan efektivitas produk yang telah dibuat yaitu Kit Elektrokimia.

Instrumen yang digunakan dalam penelitian ini adalah angket untuk validasi media. Pemilihan angket sebagai alat validasi karena Kit yang dibuat dikembangkan berdasarkan kesesuaian dengan KTSP dan buku teks. Penyusunan angket merujuk pada pedoman penilaian buku teks pelajaran kimia SMA yang dikeluarkan oleh Badan Standar Nasional Pendidikan (BSNP). Untuk mengetahui praktikalitas dan efektivitas digunakan angket yang diberikan kepada guru bidang studi kimia. Untuk mengetahui kelemahan serta kelebihan dari Kit ini diberikan angket kepada siswa yang bertujuan untuk mengetahui ketertarikannya, motivasi, isi, kelengkapan, ketepatan dan kepraktisannya. Data yang diperoleh dari angket ini 
diharapkan dapat dijadikan sebagai faktor pendukung dari data hasil validasi dari para pakar dan data uji praktikalitas dan efektifitas. Untuk evaluasi hasil belajar digunakan Lembar Soal yang diberikan kepada siswa setelah mereka melaksanakan praktikum dengan menggunakan Kit. Data evaluasi hasil belajar ini dapat digunakan sebagai pendukung pengujian efektifitas media.

Data hasil penelitian dianalisis dengan statistik deskriptif untuk mendapatkan angka rata-rata dan persentase. Teknik analisis data untuk masing-masing data hasil penelitian diuraikan sebagai berikut:

\section{Validasi Produk}

Pengolahan data validasi produk digunakan formula Kappa berikut:

$$
K=\frac{\rho_{0}-\rho_{e}}{1-\rho_{e}} \quad \text { (Boslaugh, 2008: 12) }
$$

\section{Dimana:}

$$
\begin{array}{ll}
\rho_{0} & =\text { bobot realisasi } \\
\rho_{\mathrm{e}} & =\text { bobot tidak terealisasi } \\
\mathrm{K} & =\text { nilai kappa }
\end{array}
$$

Keterangan:

1. Bobot realisasi adalah jumlah nilai yang dijawab oleh responden dibagi jumlah nilai maksimal.

2. Bobot tidak terealisasi adalah jumlah nilai maksimal dikurangi dengan jumlah nilai total yang dijawab oleh responden dibagi jumlah nilai maksimal.

Penentuan kategori penilaian berdasarkan tabel interval yang dimodifikasi dari formula Kappa tersaji pada tabel 1.

\section{Observasi Aktivitas Siswa}

Pengolahan data hasil observasi digunakan formula Kappa berikut:

$$
K=\frac{\rho_{0}-\rho_{e}}{1-\rho_{e}} \quad \text { (Boslaugh, 2008: 12) }
$$

Dimana:

$\rho_{0} \quad=$ bobot realisasi

$\rho_{\mathrm{e}} \quad=$ bobot tidak terealisasi

$\mathrm{K}=$ nilai kappa

\section{Keterangan:}

Bobot realisasi adalah jumlah nilai yang dijawab oleh responden dibagi jumlah nilai maksimal. Bobot tidak terealisasi adalah jumlah nilai maksimal dikurangi dengan jumlah nilai total yang dijawab oleh responden dibagi jumlah nilai maksimal. Penentuan kategori penilaian berdasarkan tabel interval yang dimodifikasi dari formula Kappa yang tersaji dalam tabel 2.

\section{Tes Hasil belajar}

Analisis tes hasil belajar siswa digunakan untuk mengetahui tingkat efektifitas media pembelajaran yang telah dibuat dengan mengukur tingkat ketuntasan belajar siswa berupa nilai yang diperoleh dari pelaksanaan tes. Data tes hasil belajar dianalisis secara deskriptif dengan penentuan persentase ketuntasan belajar dengan menggunakan persamaan.

$$
K B=\frac{T}{T_{t}} \times 100 \% \quad \text { (Trianto, 2009: 241) }
$$

Keterangan:

$K B=$ Ketuntasan Belajar

$T=$ Jumlah skor yang diperoleh siswa

$T_{t}=$ Jumlah skor total

Setiap siswa dikatakan tuntas belajarnya (ketuntasan individu) jika jawaban benar siswa $\geq 70,0$, sesuai dengan standar ketuntasan yang ditetapkan sekolah pada materi elektrokimia.

Tabel 1. Kategori Interval Validitas Produk dan Aktivitas Siswa

\begin{tabular}{c|c|c}
\hline Interval & Kategori Validitas Produk & Kategori Aktivitas Siswa \\
\hline$<0$ & Sangat tidak valid & Sangat Tidak Baik \\
$0-0.20$ & Tidak valid & Tidak Baik \\
$0.21-0.40$ & Kurang valid & Kurang Baik \\
$0.41-0.60$ & Cukup valid & Cukup baik \\
$0.61-0.80$ & Valid & Baik \\
$0.81-1.00$ & Sangat valid & Sangat baik \\
\hline
\end{tabular}

(Dimodifikasi dari Boslaugh, 2008 : 12) 
Tabel 2. Hasil Validasi Kit Elektrokimia

\begin{tabular}{l|l|c}
\hline No. & \multicolumn{1}{|c|}{ Indikator Penilaian } & Nilai validasi \\
\hline 1 & Kesesuaian dengan SK dan KD & 4 \\
2 & Kesesuaian dengan materi pembelajaran & 4 \\
3 & Kesesuain dengan karakteristik siswa & 3,5 \\
4 & Membangkitkan motivasi siswa & 3,5 \\
5 & Kandungan nilai & 3 \\
6 & Perawatan dan bentuk kit & 3,5 \\
\hline \multicolumn{2}{r|}{ Skor yang diperoleh } & 21,5 \\
\multicolumn{2}{r}{ Validitas (nilai Kappa) } & 0,88 \\
& Kategori & Sangat Valid \\
\hline
\end{tabular}

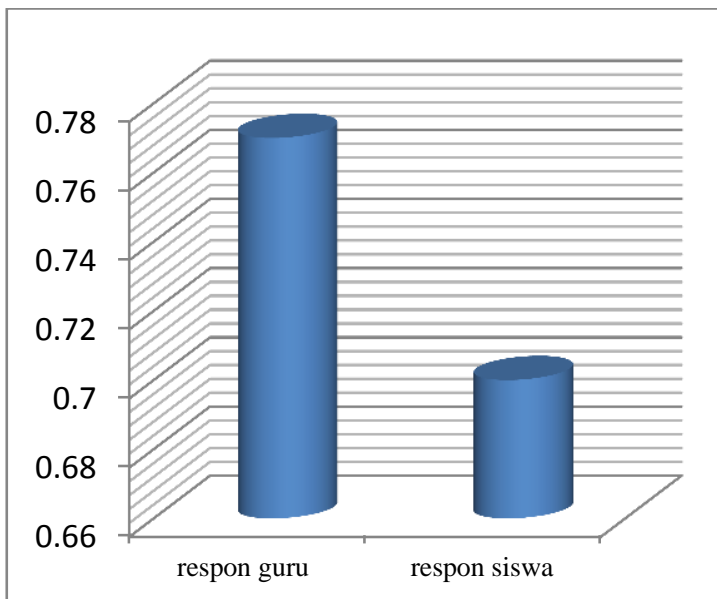

Gambar 3. Histogram Praktikalitas KIT

\section{HASIL DAN PEMBAHASAN}

\section{Tahap Analisis (Analyze)}

Pelaksanaan kurikulum dalam proses pembelajaran menuntut siswa untuk aktif dalam membangun pengetahuannya dan guru lebih berperan sebagai fasilitator. Tujuan pembelajaran kimia salah satunya adalah diharapkan siswa memiliki kemampuan untuk memperoleh pengalaman dalam menerapkan metode ilmiah melalui percobaan, sehingga siswa dapat mengolah data, menafsirkan data, dan dapat menyampaikan data hasil percobaan secara lisan dan tertulis. Siswa dapat menemukan konsep berdasarkan hasil pengamatan maupun percobaan tersebut.

Standar kompetensi media pembelajaran yang dikembangkan adalah menerapkan konsep reaksi oksidasi-reduksi dan elektrokimia dalam teknologi dan kehidupan sehari-hari. Kompetensi dasar yang dikembangkan terdiri dari:

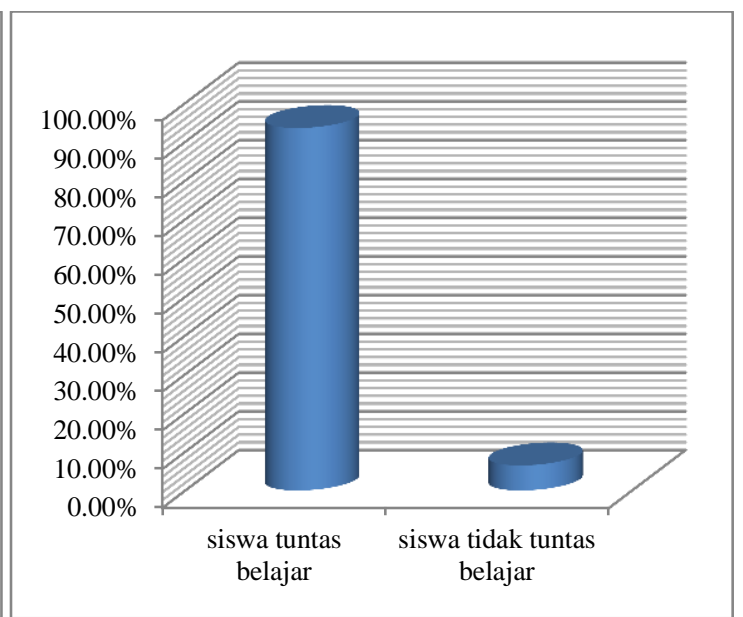

Gambar 4. Histogram Ketuntasan Hasil Belajar Siswa

1) Menerapkan konsep reaksi oksidasireduksi dalam sel elektrokimia yang melibatkan energi listrik dan kegunaannya dalam mencegah korosi dan dalam industri.

2) Menjelaskan reaksi oksidasi-reduksi dalam sel elektrolisis

3) Menerapkan hukum Faraday untuk elektrolisis larutan elektrolit.

Berdasarkan SK dan KD yang ditentukan, dalam kegiatan pembelajaran siswa harus mempunyai kemampuan minimal yang dimilikinya setelah mempelajari materi ini, diantaranya:

a) Mampu menyetarakan reaksi redoks dengan cara setengah reaksi dan cara bilangan oksidasi.

b) Mampu menerapkan konsep reaksi redoks dalam sistem elektrokimia yang melibatkan energi listrik dan kegunaannya dalam mencegah korosi dan dalam industri. 
c) Mampu menjelaskan prinsip kerja sel volta yag banyak digunakan dalam kehidupan sehari-hari (baterai,aki).

d) Mampu menjelaskan reaksi oksidasireduksi dalam sel elektrolisis dan penerapan konsep hukum Faraday.

Kemampuan minimal yang harus dimiliki siswa dapat juga dijadikan sebagai tujuan pembelajaran secara umum. Berdasarkan tujuan pembelajaran tersebut dapat dirumuskan indikator pembelajaran pada materi elektrokimia, diantaranya:

a) Menyetarakan reaksi redoks dengan cara setengah reaksi (ion elektron).

b) Menyetarakan reaksi redoks dengan cara bilangan oksidasi.

c) Menyimpulkan ciri-ciri reaksi redoks yang berlangsung spontan dari data percobaan.

d) Menggambarkan susunan sel volta atau sel galvani dan menjelaskan fungsi tiap bagiannya berdasarkan percobaan.

e) Menjelaskan bagaimana energi listik dihasilkan dari reaksi redoks dalam sel volta.

f) Menuliskan lambang sel dan reaksireaksi yang terjadi pada sel volta.

g) Menghitung potensial sel berdasarkan data potensial standar.

h) Menjelaskan prinsip kerja sel volta yang banyak digunakan dalam kehidupan (baterai, aki).

i) Menentukan reaksi di anoda dan katoda pada reaksi elektrolisis dari data percobaan.

j) Menuliskan reaksi yang terjadi di anoda dan katoda pada larutan atau cairan dengan elektroda aktif ataupun elektroda inert.

k) Menjelaskan faktor-faktor yang mempengaruhi terjadinya korosi.

1) Menjelaskan beberapa cara untuk mencegah terjadinya korosi.

m) Menerapkan konsep hukum Faraday dalam perhitungan sel elektrolisis.

n) Menuliskan reaksi elektrolisis pada penyepuhan dan pemurnian suatu logam.

Berdasarkan perumusan indikator di atas, dapat dirumuskan konsep-konsep materi elektrokimia yang harus dipelajari siswa. Konsep-konsep elektrokimia tersebut adalah: a) Konsep reaksi redoks dan aturan bilangan oksidasi.

b) Penyetaraan reaksi redoks dengan cara setengah reaksi dan cara bilangan oksidasi.

c) Sel elektrokimia terdiri dari sel volta dan sel elektrolisis.

d) Konsep sel volta.

e) Potensial sel.

f) Aplikasi sel volta dalam kehidupan.

g) Reaksi-reaksi elektrolisis (reaksi di katode dan reaksi di anode).

h) Faktor-faktor yang mempengaruhi korosi dan cara pencegahannya.

i) Hukum Faraday I dan II.

j) Elektrolisis dalam industri.

Berdasarkan SK, KD, indikator, tujuan pembelajaran, dan konsep materi elektrokimia yang telah dirumuskan diharapkan siswa aktif untuk melakukan pengamatan, percobaan, dan diskusi kelompok dalam proses pembelajaran sehingga siswa dapat membangun pengetahuannya, menemukan dan memperoleh pengalaman belajar secara langsung serta mampu memahami konsep dengan lebih bermakna dalam penerapan KD dalam kehidupan sehari-hari.

Analisis Siswa

Piaget mengemukakan tahap-tahap perkembangan kognitif yaitu; (1) tahap sensori-motoris (usia 0-2 tahun), (2) tahap pra-operasional (usia 2-7 tahun), (3) tahap operasional konkret (usia 7-11 tahun), dan (4) tahap operasional formal (usia diatas 11 tahun).

Berdasarkan teori perkembangan kognitif Piaget, siswa pada jenjang pendidikan SMA berada pada tahap operasional formal. Berarti siswa elah mampumewujudkan seluruh pekerjaannya yang merupakan hasil dari berpikir logis, mampu berpikir abstrak dan memahami prinsip-prinsip yang melandasi konsepkonsep formal, aplikasi teori dan dapat memecahkan persoalan yang bersifat hipotesis.

Dengan menggunakan media dalam proses pembelajaran diharapkan siswa lebih aktif, kreatif, dan inovatif dalam belajar. Penggunaan media pembelajaran menekankan pada proses keterlibatan siswa 
untuk mendapatkan pengalaman langsung. Belajar akan lebih bermakna jika anak "bekerja" dan "mengalami" sendiri apa yang dipelajarinya bukan sekedar mengetahuinya. Pembelajaran dengan menggunakan media memberi pengalaman belajar yang beragam pada siswa melalui interaksi dalam kelompok terutama pada saat praktikum seperti diskusi, kerjasama dalam pemecahan masalah, menemukan konsep melalui pengamatan, penyelidikan, mengumpulkan data, menginterpretasikan data, membuat kesimpulan, dan menerapkan konsep dalam kehidupan siswa sehari-hari.

\section{Tahap Desain (Design)}

Kit praktikum elektrokimia dirancang dengan beberapa pertimbangan yaitu: (1) keamanan, (2) kemudahan pemakaian dan perawatan, (3) nilai ekonomi, (4) ketepatan dalam pengukuran. Kit yang dihasilkan berupa peralatan untuk praktikum elektrokimia yang dapat dilakukan di kelas. Kit ini dikemas dalam sebuah kotak yang berisi alat-alat praktikum dan zat-zat dengan konsentrasi rendah untuk praktikum. Kit ini dibuat seaman mungkin sehingga meminimalisir resiko kecelakaan saat melakukan pekerjaan. Kit ini juga dilengkapi petunjuk pemakaian (manual book) dan lembaran hasil pengamatan.

\section{Tahap Pengembangan (Develop)}

Tahap ini bertujuan untuk menghasilkan Kit yang layak digunakan untuk pembelajaran Elektrokimia. Prototipe instrumen penilaian media pembelajaran dan alat evaluasi berupa soal tes hasil belajar diberikan pada validator untuk mengetahui validitas media pembelajaran dan alat evaluasi yang telah dibuat. Berdasarkan hasil validasi diketahui bahwa media pembelajaran dan alat evaluasi yang telah dibuat dinyatakan valid dengan beberapa perbaikan. Oleh karena itu Kit tersebut direvisi berdasarkan saran dan masukan dari validator, kemudian dilakukan ujicoba.

Hasil validasi kit yang dikembangkan dinilai oleh validator menggunakan Lembar Validasi Kit Elektrokimia. Disajikan pada Tabel 2. Angka yang dimasukan dalam tabel menunjukkan skor penilaian dari validator. Pengambilan kesimpulan dari hasil validasi berdasarkan kriteria yang terdapat dalam Metode Penelitian. Hasil validasi Kit Elektrokimia yang ditampilkan pada Tabel 3 menunjukkan rata-rata berkategori valid. Berdasarkan analisis data hasil penilaian terhadap kit, diperoleh nilai rata-rata 0,88 dan termasuk kategori sangat valid. Nilai rata-rata tersebut mempunyai makna bahwa kit yang dikembangkan sudah sesuai dengan kompetensi, materi pembelajaran, strategi, dan metoda pembelajaran. Kit dapat memotivasi siswa karena kit sesuai dengan karakteristik siswa. Kandungan nilai dalam kit termasuk tinggi dan mudah dalam hal perawatan. Saransaran yang diberikan oleh validator diantaranya:

1) Perbaikan ukuran alat-alat yang digunakan dalam kit.

2) Usahakan dalam satu kotak dapat memuat dua set alat praktikum elektrokimia.

Ujicoba dilakukan dengan mengoperasionalkan media pembelajaran yang telah divalidasi oleh pakar kepada siswa. Ujicoba ini dilakukan di SMA Negeri 1 Gunung Talang Kabupaten Solok pada siswa kelas XI IPA 1. Berdasarkan hasil pengamatan dan pengisian angket oleh guru dan siswa yang telah belajar elektrokimia dengan menggunakan Kit Elektrokimia diketahui bahwa media yang digunakan dalam proses pembelajaran elektrokimia tersebut pempunyai praktikalitas yang baik, sehingga dapat digunakan oleh guru sebagai praktisi pengguna media dan siswa dalam proses pembelajarannya. Penyajian data praktikalitas media pembelajaran berdasarkan angket respon guru dan angket respon siswa pada Gambar 3.

Berdasarkan Gambar 3 dapat diketahui bahwa media pembelajaran yang telah dibuat praktis digunakan oleh guru dalam proses belajar-mengajar dengan nilai kepraktisan sebesar 0,77 dari skala 0 sampai 1, dan media juga dapat membantu siswa dalam memahami pelajaran elektrokimia yang terlihat dari nilai kepraktisan media berdasarkan angket respon siswa sebesar 0,70 dari skala 0 sampai 1 . 
Hasil belajar diperoleh dari Lembar Soal yang diberikan setelah pelaksanaan pembelajaran da percobaan menggunakan Kit Elektrokimia. Hasil belajar yang diperoleh merupakan penilaian kognitif. hasil belajar yang diperoleh disajikan secara ringkas pada Gambar 4.

Berdasarkan Gambar 4 dapat dilihat bahwa pembelajaran kimia dengan menggunakan Kit pada materi elektrokimia dapat meningkatkan hasil belajar siswa. Hal ini terlihat dari persentase individual yang mencapai ketuntasan belajar sebesar $93,54 \%$, hanya $6,46 \%$ siswa yang tidak tuntas.

\section{PENUTUP}

Berdasarkan hasil penelitian dan hasil analisis data, dapat disimpulkan bahwa:

a. Media pembelajaran Elektrokimia dalam bentuk Kit yang dihasilkan memiliki validitas sangat baik yaitu sebesar 0,88 . Keterlaksanaan pembelajaran berlangsung dengan baik yang juga diperlihatkan dari angket respon siswa dengan nilai kepraktisan 0,70 dan angket respon guru dengan nilai kepraktisan 0,77 terhadap media pembelajaran yang digunakan. Pada umumnya mereka senang belajar dengan Kit yang digunakan untuk proses praktikum. Hal ini menunjukkan bahwa praktikalitas Kit yang dikembangkan baik dan dapat digunakan dalam proses pembelajaran di kelas.

b. Hasil belajar siswa dengan menggunakan media pembelajaran yang sudah dikembangkan cukup baik. Ini terlihat dari hasil belajar siswa yang mencapai KKM sebesar 93,54\% dan yang tidak mencapai KKM sebesar $6,46 \%$. Hal ini menunjukkan bahwa efektifitas pembelajaran dari segi hasil belajar cukup baik

\section{UCAPAN TERIMA KASIH}

Penulis mengucapkan terima kasih kepada tim redaksi Jurnal Pelangi yang banyak memberikan masukan dan perbaikan dalam penulisan artikel ini.

\section{DAFTAR RUJUKAN}

Akker, Jan Van Den dan Tj. Plomp. 2006. Educational Design Research. London and New York: Routledge Taylo and Francis Group.

Anderson, Ronald H. 1994. Pemilihan dan Pengembangan Media untuk Pembelajaran. Penej. Yusufhadi Miarso, dkk. Jakarta: Rajawali Press.

Arifin, Mulyati. 2005. Strategi Belajar Mengajar Kimia. Malang: Universitas Negeri Malang.

Aunurrahman. 2009. Belajar dan Pembelajaran. Bandung: Alfabeta.

Boslaugh, Sarah and Paul Andrew Wattern. 2008. Statistics in a Nutshell, a desktop quick reference. Beijing, Cambridge, Famhan, Koln, Sebastopol, Taipei, yokyo: O'reilly.

Borg, W. R., Gall., M., D. 1979. Educational Research. An Introduction. New York an London, Longman Inc.

Brown, James W. 1977. AV Instruction Technology, Media, and Methods fifth Edition. New York: McGrawHill Book Company.

Curzon, Leslie Basil. 2004. Teaching in Further Education; An Outline of Principles and Practice, Sixth Edition. New York: Continum.

Chomsin S Widodo dan Jasmadi. 2008. Panduan Menyusun Bahan Ajar Berbasis Kompetensi. Jakarta: Elex Media Komputindo.

Departemen Pendidikan Nasional. 2006. Kurikulum Tingkat Satuan Pendidikan Sekolah Menengah Atas dan Madrasah Aliyah. Jakarta: Badan Standar Nasional Pendidikan (BSNP).

Departemen Pendidikan Nasional. 2008a. Panduan Pengembangan Bahan Ajar. Departemen Pendidikan Nasional, Direktorat Jenderal Manajemen Pendidikan Dasar dan Menengah, Direktorat Pembinaan Sekolah Meengah Atas.

Departemen Pendidikan Nasional. 2008. Pengembangan Rencana Pelaksanaan Pembelajaran(RPP). Departemen Pendidikan Nasional, Direktorat Jenderal Manajemen 
Pendidikan Dasar dan Menengah, Direktorat Pembinaan Sekolah Menengah Atas.

Departemen Pendidikan dan Kebudayaan. 1994. Kamus Besar Bahasa Indonesia Edisi Kedua. Jakarta: Balai Pustaka

Hamalik, Oemar. 1997. Media Pendidikan. Bandung: PT. Citra Aditya bakti.

Heinich, Robert. 1985. Instructional Media. New York: John Wiley \& Sons.

King, Kenneth P. 2002. Technology Science Teaching, and Literacy. New York: Kluwer Academic/ Plenum Publisher

Latief, M. Adnan. 2009. Penelitian Pengembangan. Malang: Universitas Negeri Malang.

McKenney, Susan Emily. 2001. ComputerBased Support for Science Education Materials Developers in Africa: Exploring potentials. Enschede: PrintPartners Ipskamp.

Mulyasa, E. 2007. Kurikulum Tingkat satuan Pendidikan. Bandung: Remaja Rosdakarya.

Munadi, Yudhi. 2008. Media Pembelajaran sebuah Pendekatan Baru. Jakarta: Gaung Persada Press.

Noerdin, Isjrin. 1995. Praktikum sain IPA di SD dan Sains Kit. Padang/IKIP.

Novak, Joseph D. 1984. Learning how to Learning. Cambridge: Cambridge University Press.

OECD. May 2005. An Evaluation of Educational Research and Development in Iceland. Iceland:
Icelandic Centre for Research and Ministry for Education, Science and Culture.

Romiszowski, AJ. 1988. The Selection snd Use of Instructional Media. New York:Kogan, London/ Nichols Publishing.

Sanjaya, Wina. 2008. Kurikulum dan Pembelajaran: Teori dan Praktik Pengembangan Kurikulum Tingkat Satuan Pendidikan. Jakarta: Kencana Prenada Media Group.

Sumiaty. 2002. Pembuatan Kit Praktikum untuk Pembelajaran Gugus Fungsional di Kelas 2 SMU( skripsi). Padang: Jurusan Kimia UNP.

Trianto. 2007. Model Pembelajaran Terpadu dalam Teori dan Praktek. Jakarta: Prestasi Pustaka Publisher.

Trianto. 2009. Mendesain Model Pembelajaran Inovatif Progresif; Konsep, Landasan, dan Implementasinya pada Kurikulum Tingkat Satuan Pendidikan (KTSP). Jakarta: Kencana Prenada Media Group.

www.lifeskill.net. Senin, 23 Juni 2003. Makalah seminar Training of Trainer Pendidikan Berorientasikan Keterampilan Hidup (life skill) Pendidikan Agama di PPPG Keguruan. Dinas Pendidikan Nasional.

http://id.wikipedia.org/wiki/Jean_Piaget. Tahap-tahap perkembangan kognitif Piaget. Diakses 10 April 2010 